NASA TECHNICAL NOTE

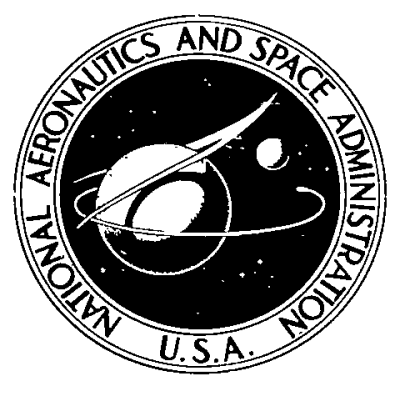

NASA IN D-6562

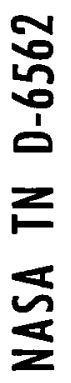

LOAN COPY: RETURN

AFWL (DO $i(L)$

KIRTLAND AFB, N. M.

\title{
MACH 1 OXIDATION OF
}

THORIATED NICKEL CHROMIUM

AT $1204^{\circ} \mathrm{C}\left(2200^{\circ} \mathrm{F}\right)$

by Carl E. Lowell and William A. Sanders

Lewis Research Center

Cleveland, Obio 44135

national aeronautics and SPaCe adMinIStration - WASHINGTON, D. C. - NOVEMber 1971 
1. Report No.
NASA TN D-6562

4. Title and Subtitie

MACH 1 OXIDATION OF THORIATED NICKEL CHROMIUM AT $1204^{\circ} \mathrm{C}\left(2200^{\circ} \mathrm{F}\right)$

7. Author(s)

Carl E. Lowell and William A. Sanders

9. Performing Organization Name and Address

Lewis Research Center

National Aeronautics and Space Administration

Cleveland, Ohio 44135

12. Sponsoring Agency Name and Address

National Aeronautics and Space Administration

Washington, D.C. 20546

15. Supplementary Notes
2. Government Accession No.

November 1971

6. Performing Organization Code

8. Performing Organization Report No.

E-6488

10. Work Unit No

134-03

11. Contract or Grant No

13. Type of Report and Period Covered Technical Note

14. Sponsoring Agency Code

16. Abstract

TD NiCr was exposed to a Mach 1, 1-atmosphere gas stream at $1204^{\circ} \mathrm{C}\left(2200^{\circ} \mathrm{F}\right)$ for times up to 50 hours. Weight change, metal thickness loss, X-ray diffraction, metallographic, and electron microprobe analyses were made. Neither surface preparation nor thermal cycling had an appreciable effect on the results. Initially, $\mathrm{Cr}_{2} \mathrm{O}_{3}$ formed and volatilized, allowing a rapid metal loss rate of $40 \mu \mathrm{m}$ per hour. After about 1 hour the $\mathrm{Cr}_{2} \mathrm{O}_{3}$ broke down, resulting in an NiO overgrowth. The metal loss rate then slowed to $2.5 \mu \mathrm{m}$ per hour and remained constant to 50 hours.

17. Key Words (Suggested by Author(s))

Oxidation; High velocity; Superalloy; Nickel-

18. Distribution Statement

Unclassified - unlimited

chromium alloy; Surface finish; Electron

probe; X-ray diffraction, Burner rig

19. Security Classif. (of this report)

Unclassified

20. Security Classif: (of this page) Unclassified
21. No. of Pages

23
22. Price ${ }^{*}$

$\$ 3.00$

\footnotetext{
*For sale by the National Technical Information Service, Springfield, Virginia 22151
} 


\title{
MACH 1 OXIDATION OF THORIATED NICKEL CHROMIUM AT $1204^{\circ} \mathrm{C}\left(2200^{\circ} \mathrm{F}\right)$ \\ by Carl E. Lowell and William A. Sanders \\ Lewis Research Center
}

\begin{abstract}
SUMMARY
Electropolished and ground samples of $\mathrm{TD} \mathrm{NiCr}$ were exposed to a 1-atmosphere, Mach 1 gas stream at $1204^{\circ} \mathrm{C}\left(2200^{\circ} \mathrm{F}\right)$ for times up to 50 hours. The samples were subjected to both cyclic and isothermal exposure. Weight change, metal loss, X-ray diffraction, metallographic, and electron microprobe analyses were performed. Neither surface preparation nor cyclic-against-isothermal-exposure conditions had a strong effect on the oxidation behavior of the alloy. Initially, a $\mathrm{Cr}_{2} \mathrm{O}_{3}$ layer was formed whose volatilization resulted in a very rapid loss of metal: more than 40 micrometers in the first hour. At about 1 hour the $\mathrm{Cr}_{2} \mathrm{O}_{3}$ layer broke down and NiO began to cover the surface. By 5 hours the NiO had covered the surface and the rate of loss slowed. The rate-controlling step was diffusion of $\mathrm{Cr}$ through NiO. By 50 hours the sample had lost approximately 200 micrometers in thickness.
\end{abstract}

\section{INTRODUCTION}

Thoriated nickel chromium (TD NiCr) is a nickel - 20-percent-chromium alloy which is dispersion strengthened with 2-percent $\mathrm{ThO}_{2}$. It is being considered for use in advanced jet engines and as a part of the thermal protection system for the proposed space shuttle. This consideration is a result of its good high-temperature strength and reportedly good oxidation resistance. The oxidation resistance of this alloy depends on the formation of a protective barrier of chromium oxide and/or nickel chromium spinel. These oxides seem to effectively separate the underlying alloy from the oxidizing environment as long as they are in place. However, many investigators (e.g., refs. 1 and 2) have shown that these oxides are quite volatile particularly above $1000^{\circ} \mathrm{C}\left(1832^{\circ} \mathrm{F}\right)$.

Since a volatile oxide would not be expected to provide a good oxidation barrier, the reported volatility of these oxides would seem to be in conflict with the low oxidation rates for $\mathrm{TD} \mathrm{NiCr}$ reported in references 3 to 6 at temperatures as high as $1200^{\circ} \mathrm{C}\left(2192^{\circ} \mathrm{F}\right)$. 
An added apparent anomaly is the fact that vaporization rates calculated by the Langmuir equation (ref. 7, see appendix) using vapor pressures of reference 8 are even higher, by several orders of magnitude, than those observed for chromium-bearing oxides in static tests (refs. 3 to 6 ). This discrepancy between calculated and measured vaporization rates was due to the reflection and redeposition of vapor species on the sample. A similar phenomenon was observed by Fryburg (ref. 9) in the case of $\mathrm{PtO}_{2}$. Thus, measured rates of chromium oxide loss were lower than those calculated from the Langmuir equation, in which it is assumed that every molecule that leaves the surface is not reflected but condenses in some other part of the system.

These observations are relevant to applications in which the gaseous environment is moving with respect to the oxidizing surfaces. This occurs both in gas turbine rotor blades and stator vanes as well as the thermal protection system of the space shuttle. In such cases, the volatile species may be swept away, thus increasing the observed mass loss rate, which should then approach the rate calculated from the Langmuir equation. This increased mass loss rate of $\mathrm{Cr}_{2} \mathrm{O}_{3}$ under flowing gas conditions has been observed by Graham and Davis (ref. 10). Thus, it can be reasonably anticipated that the reported good oxidation resistance of $\mathrm{TD} \mathrm{NiCr}$ might be seriously degraded in a flowing gas test. Indeed, Johnston and Ashbrook (ref. 11) have observed a gas velocity effect on the mass loss for $\mathrm{TD} \mathrm{NiCr}$ at $1093^{\circ} \mathrm{C}\left(2000^{\circ} \mathrm{F}\right)$; and Centolanzi (ref. 12) has observed accelerated attack in an arc-jet environment at low pressures.

The primary objectives of the investigation reported herein were twofold:

(1) To determine oxidation rates of $\mathrm{TD} \mathrm{NiCr}$ at $1204^{\circ} \mathrm{C}\left(2200^{\circ} \mathrm{F}\right)$ under conditions of high gas flow

(2) To determine the mode of oxide formation and breakdown under high gas flows A secondary objective was to determine the effect of sample surface preparation on the oxidation behavior under high-gas-velocity conditions. Work on this last objective was prompted by the observations in reference 6 . In that investigation a strong influence of surface preparation on the mechanism of the static oxidation of TD NiCr was observed. Surface grinding was found to promote the formation of $\mathrm{Cr}_{2} \mathrm{O}_{3}$, while polished surfaces promoted the additional formation of $\mathrm{NiO}$ and $\mathrm{NiCr}_{2} \mathrm{O}_{4}$.

The program reported herein was conducted in a burner rig facility (ref. 11) which produces combustion gases at approximately Mach 1 velocity and 1-atmosphere pressure. This facility is intended to simulate the gas turbine environment. While the pressure conditions of the space shuttle are not met, it is felt that the same mechanism of oxidation will take place and that the data acquired here are qualitatively the same as those acquired from lower pressure, high-velocity tests.

Samples were heated at $1204^{\circ} \mathrm{C}\left(2200^{\circ} \mathrm{F}\right)$ both cyclically and isothermally for times up to 50 hours. Both mass change and metal thickness change were measured. Surface scales were identified by X-ray diffraction, and oxidized samples were studied by metallography and electron microprobe. 


\section{MATERIALS AND SPECIMEN PREPARATION}

The composition of $\mathrm{TD} \mathrm{NiCr}$ is given in table I. This composition is typical for TD NiCr and complies with the supplier's specifications (ref. 13).

The TD NiCr test specimens were cut from 0.64-centimeter (1/4-in.) thick plate and ground to dimensions as shown in figure 1. Some specimens were electropolished in a solution consisting of 70 parts by volume methanol and 30 parts by volume $\mathrm{HNO}_{3}$. The polishing solution was cooled to below $-10^{\circ} \mathrm{C}\left(14^{\mathrm{O}} \mathrm{F}\right)$.

TABLE I. - CHEMTCAL

COMPOSITION OF

$\mathrm{TD} \mathrm{NiCr}$

\begin{tabular}{|l|c|} 
Constituent & $\begin{array}{c}\text { Content, } \\
\text { wt. \% }\end{array}$ \\
\hline $\mathrm{Cr}$ & 19.70 \\
$\mathrm{ThO}_{2}$ & 2.1 \\
$\mathrm{Ni}$ & $\mathrm{Bal}$ \\
$\mathrm{N}$ & .030 \\
$\mathrm{C}$ & .0269 \\
$\underline{\mathrm{S}}$ & .0056 \\
\hline
\end{tabular}

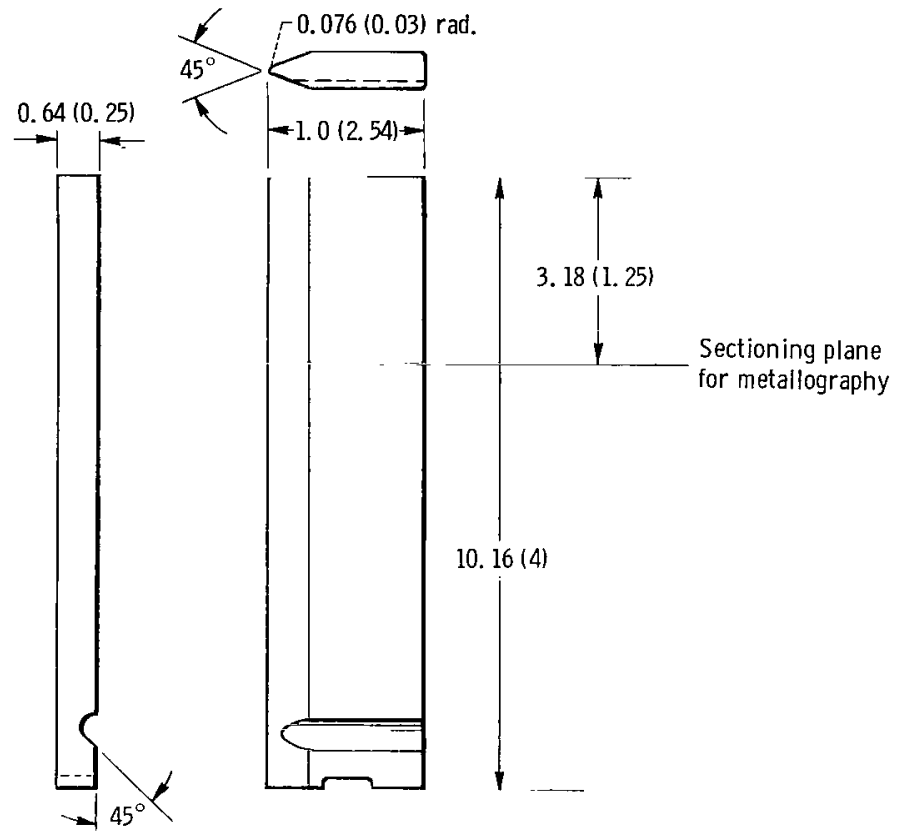

Figure 1. - Specimen used in high-gas-velocity oxidation tests. (Dimensions are in $\mathrm{cm}$ (in.).)

The width and thickness of each specimen were measured at the metallographic sectioning plane (fig. 1). A bench micrometer with a precision of 1 micrometer was used for these measurements. All specimens were then cleaned in alcohol, dried, and weighed to \pm 0.2 milligram.

\section{APPARATUS AND TEST PROCEDURES}

Figure 2 shows a photograph and a schematic representation of the high-gas-velocity 


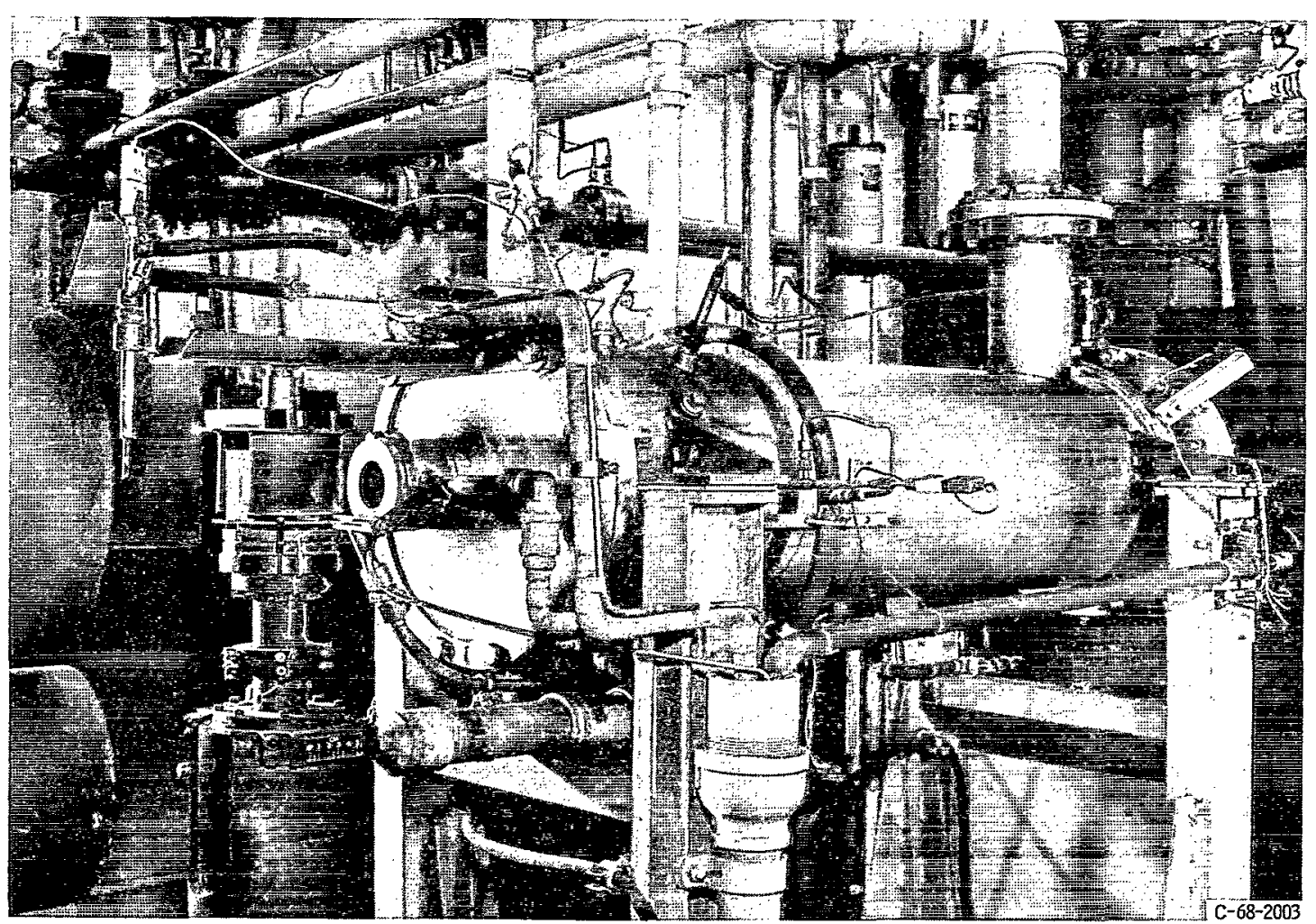

(a) Overall view.

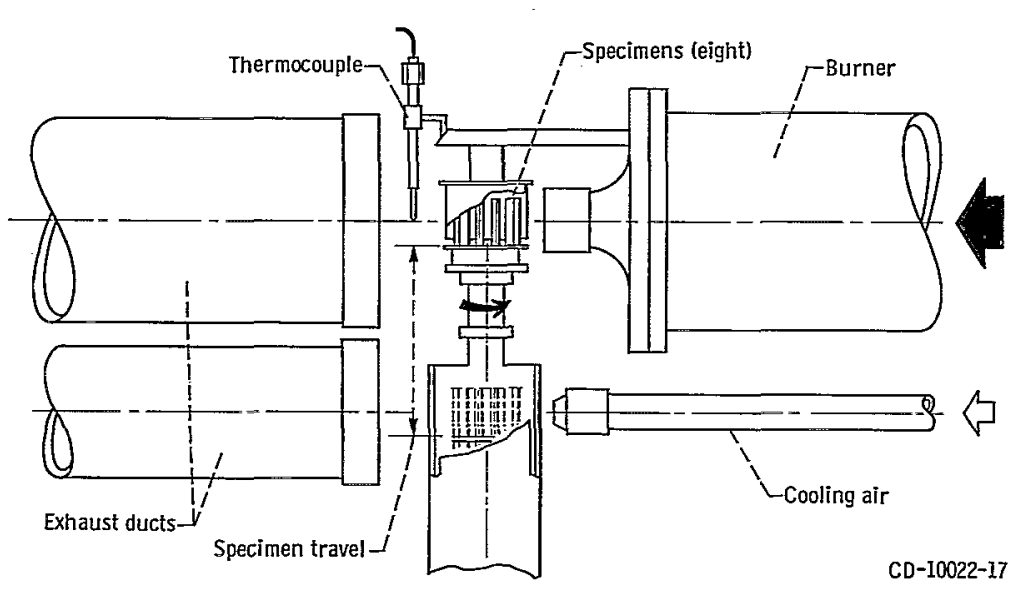

(b) Schematic diagram.

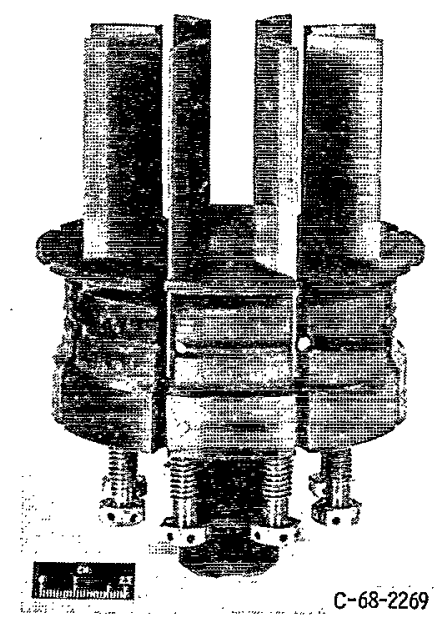

(c) Specimen holder assembly.

Figure 2. - High-gas-velocity oxidation apparatus. 
oxidation apparatus used in this investigation and described in detail in reference 11. The Jet A-1 fueled apparatus was operated at a combustion gas velocity of Mach 1 in both a cyclic and an isothermal mode. The specimens were rotated in the air-rich combustion gas stream with the tapered edges of the specimens closest to the nozzle. Ground and electroplished specimens run cyclically were heated at $1204^{\circ} \mathrm{C}\left(2200^{\circ} \mathrm{F}\right)$ for 1 hour and then lowered into a Mach 1 cold-air blast for 3 minutes. This cycle was repeated for the intended test duration. Isothermal exposure of ground and electropolished specimens was effected by continuous heating of specimens at $1204^{\circ} \mathrm{C}\left(2200^{\circ} \mathrm{F}\right)$ in approximately 15-hour maximum increments (two successive day shifts of burner operation). Required shutdowns at the end of two shifts of operation were without forced-air cooling. This resulted in the 25-hour samples having two cycles and the 50-hour samples having four cycles. Temperatures were measured using a slip ring thermocouple arrangement connected to a spare $\mathrm{TD} \mathrm{NiCr}$ specimen in the rotating fixture and were controlled by means of a stationary control thermocouple downstream of the test specimens. Temperature checks were made with a calibrated optical pyrometer. Specimen temperatures were maintained within $\pm 15^{\circ} \mathrm{C}\left(25^{\circ} \mathrm{F}\right)$ of the desired $1204^{\circ} \mathrm{C}\left(2200^{\circ} \mathrm{F}\right) \mathrm{ex}-$ posure temperature. Both the isothermal and cyclic tests were begun with five test specimens and three spare TD NiCr specimens in the eight-place holder. Test specimens were removed and replaced with spare $\mathrm{TD} \mathrm{NiCr}$ specimens after 1, 5, 10, and 25 hours of exposure. The longest test exposure was 50 hours.

After exposure the specimens were weighed and photographed and surface scales were analyzed in situ by X-ray diffraction. The specimens were then sectioned as shown in figure 1 and metallographically polished. Metal width and thickness measurements exclusive of oxide scales were made on the polished sections. These measurements were made with a filar eyepiece to a precision of +2 micrometers.

The specimen sections were then examined in both the polished and etched conditions. The electrolytic etchant used delineated both chromium-depletion regions and grain boundaries. This etchant consisted of 100 milliliters of $\mathrm{H}_{2} \mathrm{O}, 2$ grams of chromic acid, and 10 milliliters of $\mathrm{H}_{2} \mathrm{SO}_{4}$ at 3 to 5 volts.

Selected metallographic samples were also analyzed by means of the electron microprobe. Probe traces for $\mathrm{Ni}, \mathrm{Cr}$, and Th concentrations were obtained.

\section{RESULTS AND DISCUSSION}

TD NiCr was oxidized at $1204^{\circ} \mathrm{C}\left(2200^{\circ} \mathrm{F}\right)$ for times up to 50 hours in a Mach 1 gas stream. The results obtained are discussed in this section. The oxidation behavior of TD NiCr in this environment was judged by weight changes, X-ray diffraction, metallography, microprobe analysis, and metal thickness loss. The results are presented and 
discussed in that order and the discussion is concluded with a proposed model of the oxidation mechanism.

\section{Weight Change}

The weight change data for all samples are plotted in figure 3. All samples lost weight continuously from the first measurement at 1 hour. There were no systematic differences between the ground and electropolished samples. In fact, there was only a slight difference between the cyclic and isothermal data. The difference was the opposite from what would be expected in that the cyclically exposed samples lost less weight than the isothermally exposed samples. If spalling were an important part of this oxidation process, the cyclically tested samples, which have more opportunity to spall, would be expected to lose more weight.

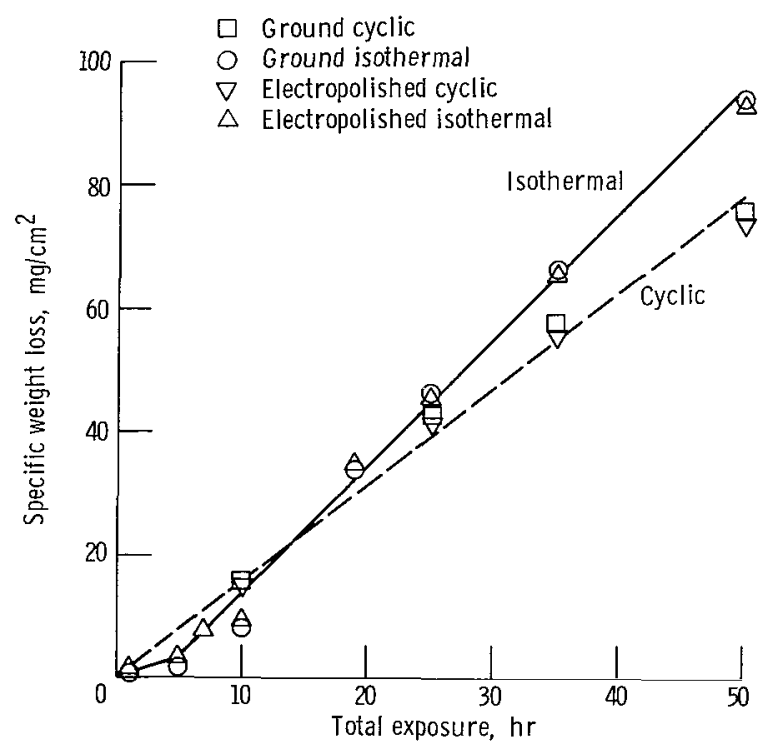

Figure 3. - Weight change of ground and electropolished $\mathrm{TD} \mathrm{NiCr}$ resulting from cyclic and isothermal exposure at $1204^{\circ} \mathrm{C}\left(2200^{\circ} \mathrm{F}\right)$ in high-gas-velocity oxidation apparatus. Cycle, 1 hour at $1204^{\circ} \mathrm{C}\left(2200^{\circ} \mathrm{F}\right), 3 \mathrm{~min}-$ utes forced-air cool to room temperature.

\section{Sample Appearance}

Figure 4 shows the ground samples as they appeared after isothermal oxidation for times up to 50 hours. The electropolished samples, both cyclically and isothermally exposed, and the ground cyclically exposed samples all had the same appearance as the ground, isothermally exposed samples and are therefore not shown. 


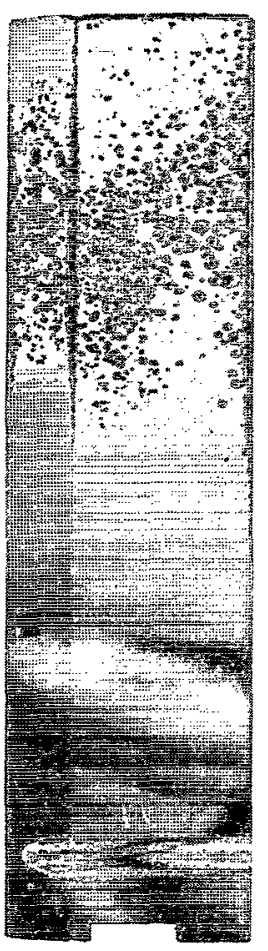

Exposure, hr: 1

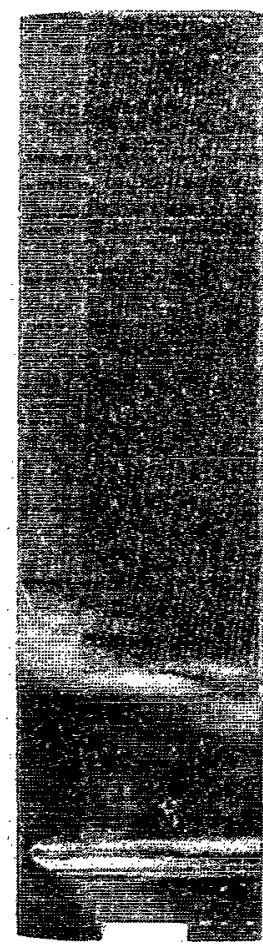

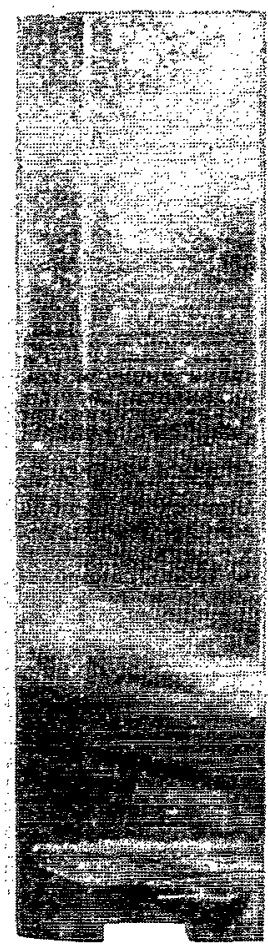

10

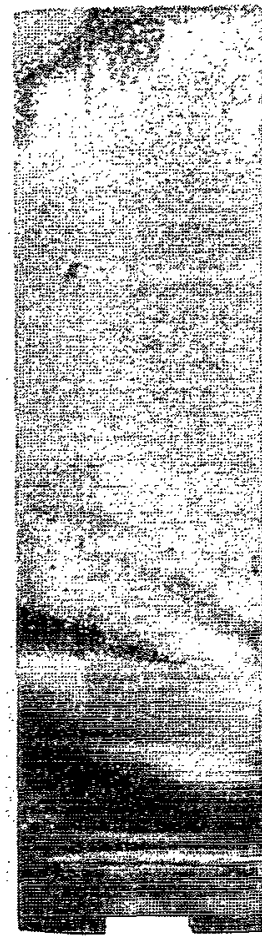

25

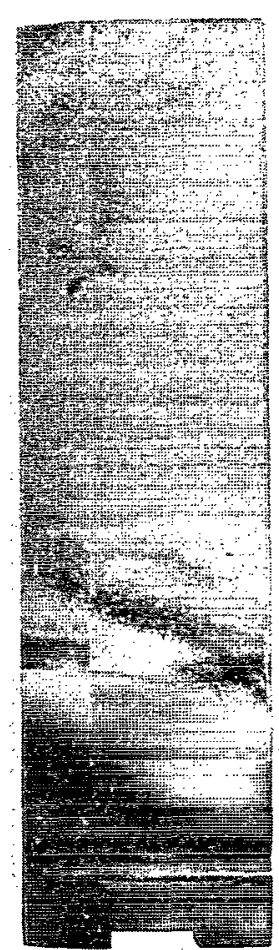

50

Figure 4. - Ground TD NiCr oxidation specimens after isothermal exposure at $1204^{\circ} \mathrm{C}\left(2200^{\circ} \mathrm{F}\right)$ in high-gas-velocity oxidation apparatus.

The 1-hour-exposed sample has a complex morphology in the hot zone. The surface is covered with gray blisters (later identified as NiO, see section Metallography) erupting from a dark gray-green background (later identified as $\mathrm{Cr}_{2} \mathrm{O}_{3}$ ). This indicates that the initial scale was $\mathrm{Cr}_{2} \mathrm{O}_{3}$ (confirmed in the following section). At 1 hour the $\mathrm{Cr}_{2} \mathrm{O}_{3}$ was in the process of breaking down and allowing $\mathrm{NiO}$ to form. At a magnification of $\times 10$ (fig. 5), the blisters are shown in greater detail. They appear to be plateaus which start at isolated spots, grow, and coalesce. Another phase appears to be present at the edges of the plateaus. This was later shown to be $\mathrm{NiCr}_{2} \mathrm{O}_{4}$ (see the next section). At longer times, the surface in the hot zone is uniformly a green color which progressively gets lighter. These surfaces were later (see the next section) shown to be predominantly NiO.

\section{X-Ray Diffraction}

The results of the in situ X-ray diffraction are presented in table II. The strength of the oxide patterns are estimates and are subject to the usual sources of error (e.g., 


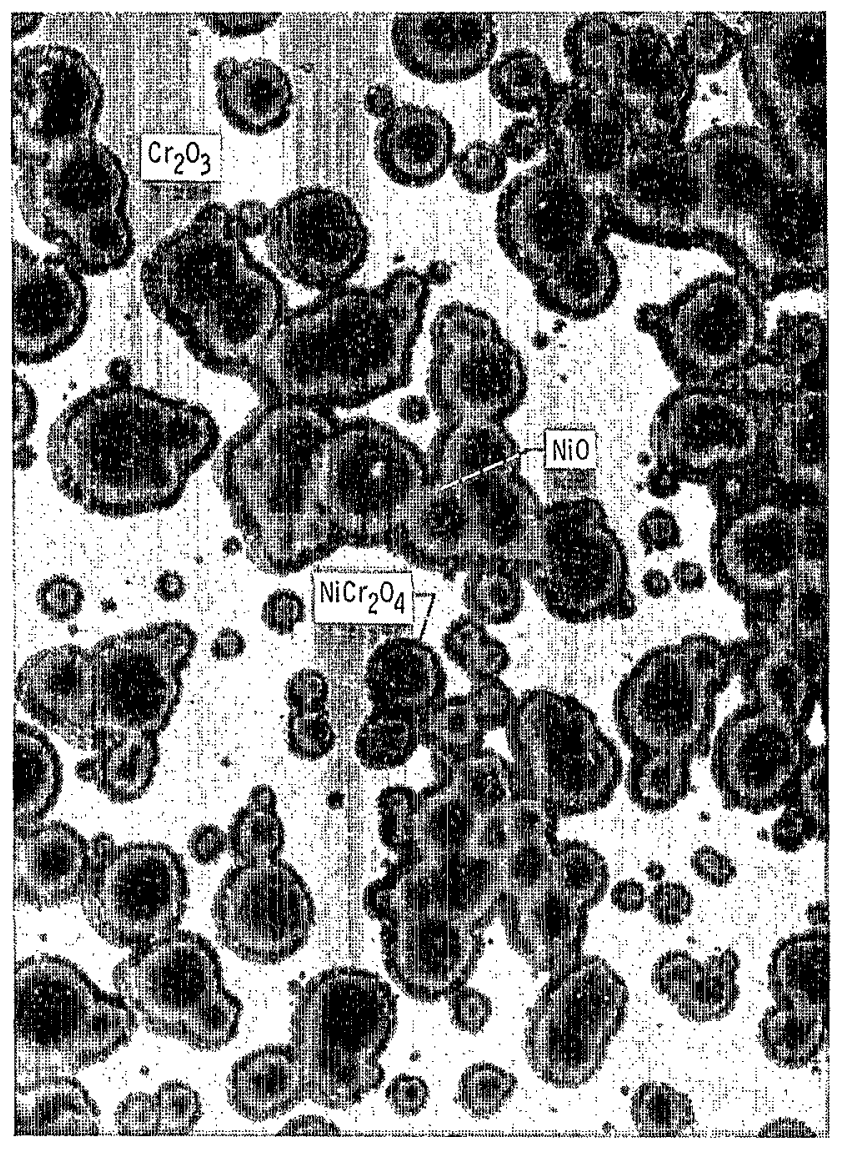

$1 \mathrm{~mm}$

Figure 5. - Surface of TD NiCr burner rig blade ground and exposed isothermally at $1204^{\circ} \mathrm{C}\left(2200^{\circ} \mathrm{F}\right)$ for I hour. $\mathrm{X} 10$.
TABLE II. - OXIDES DETERMINED BY X-RAY DIFFRACTION ON TD NiCr CYCLICALLY OR ISOTHERMALLY EXPOSED AT $1204^{\circ} \mathrm{C}\left(2200^{\circ} \mathrm{F}\right)$ IN HIGH-GAS-VELOCITY OXIDATION APPARATUS FOR VARIOUS TIMES

[Cycle, $1 \mathrm{hr}$ at $1204^{\circ} \mathrm{C}\left(2200^{\circ} \mathrm{F}\right), 3 \mathrm{~min}$ forced-air cool to room temperature.]

\begin{tabular}{|c|c|c|c|c|c|}
\hline \multirow{2}{*}{$\begin{array}{c}\text { Surface condi- } \\
\text { tion }\end{array}$} & \multirow{2}{*}{$\begin{array}{c}\text { Exposure } \\
\text { time, } \\
\text { hr }\end{array}$} & \multirow[t]{2}{*}{ Cyclic } & \multicolumn{3}{|c|}{ Adhering surface oxides } \\
\hline & & & $\mathrm{NiO}$ & $\mathrm{Cr}_{2} \mathrm{O}_{3}$ & $\mathrm{NiCr}_{2} \mathrm{O}_{4}$ \\
\hline \multirow[t]{8}{*}{ Ground } & $a_{1}$ & No & $\mathrm{c}_{\mathrm{S}}$ & $S$ & W \\
\hline & $b_{1}$ & & ND & $\mathrm{s}$ & $\mathrm{ND}$ \\
\hline & 5 & & s & $\mathrm{ND}$ & \\
\hline & 10 & & 1 & $\mathrm{ND}$ & \\
\hline & 25 & & & $\mathrm{~W}$ & \\
\hline & 50 & $\gamma$ & & $\mathrm{ND}$ & \\
\hline & 25 & Yes & & ND & \\
\hline & 50 & Yes & $\gamma$ & $\mathrm{W}$ & $\downarrow$ \\
\hline \multirow[t]{7}{*}{ Electropolished } & 1 & No & ND & s & W \\
\hline & 5 & & $s$ & $\mathrm{ND}$ & $\mathrm{ND}$ \\
\hline & 10 & & & ND & $\mathrm{ND}$ \\
\hline & 25 & & & W & W \\
\hline & 50 & $\psi$ & & ND & $\mathrm{ND}$ \\
\hline & 25 & Yes & & $\mathrm{VW}$ & ND \\
\hline & 50 & Yes & 1 & W & $W$ \\
\hline
\end{tabular}

${ }^{\mathrm{a}}$ In mottled area.

$b_{\text {In uniform gray-green area. }}$

${ }^{c} \mathrm{~S}=$ strong; $\mathrm{W}=$ weak; $\mathrm{VW}=$ very weak; $\mathrm{ND}=$ not detected. 
unequal absorption, preferred orientation, etc.). However, when combined with probe traces they can yield useful information about the composition of the scale. The main point of interest in these data is that $\mathrm{NiO}$ is the major oxide on all but the 1-hourexposed samples. Indeed, $\mathrm{Cr}_{2} \mathrm{O}_{3}$ and $\mathrm{NiCr}_{2} \mathrm{O}_{4}$, the only other possible phases, are seldom detected and at the most appear as weak patterns. The 1-hour-exposed samples, on the other hand, show strong indications of $\mathrm{Cr}_{2} \mathrm{O}_{3}$ being present. The blistered, ground sample shows both $\mathrm{Cr}_{2} \mathrm{O}_{3}$ and $\mathrm{NiO}$ to be strong in the blistered area but shows only $\mathrm{Cr}_{2} \mathrm{O}_{3}$ in the uniform zone. The 1-hour-exposed electropolished sample which had not started to form blisters had only $\mathrm{Cr}_{2} \mathrm{O}_{3}$. These data give support to the observation that $\mathrm{Cr}_{2} \mathrm{O}_{3}$ is the first oxide to form, but that it subsequently breaks down, allowing $\mathrm{NiO}$ to grow over the entire surface.

\section{Metallography}

In (figs. 6 to 8), as in the case of the surface photography (fig. 4), only the ground isothermal exposure sample sequence is shown. The other samples, the cyclically exposed ground sample and the cyclically and isothermally exposed polished samples, had exactly the same sequential appearance as those in figures 6 to 8 and are therefore not shown. All observations made in this section apply to ground and electropolished, cyclic and isothermal samples.

Figure 6 shows the cross section of the blistered, ground, 1-hour-exposed sample of figure 5. The blistered areas are trilayered. These layers are, starting at the metal-oxide interface: $\mathrm{Cr}_{2} \mathrm{O}_{3}, \mathrm{NiCr}_{2} \mathrm{O}_{4}$, and $\mathrm{NiO}$ with the $\mathrm{NiO}$ being the thickest layer. The oxides were identified by a combination of $\mathrm{X}$-ray diffraction and microprobe (see following section). The $\mathrm{NiCr}_{2} \mathrm{O}_{4}$ layer shows pronounced pullout during sample preparation, possibly indicating poor adhesion between oxide layers. Between the blisters the oxide consists of a very thin $\mathrm{Cr}_{2} \mathrm{O}_{3}$ layer. The light etching region in the metal just beneath the oxide is a $\mathrm{Cr}$-depletion zone.

After 5 hours, the oxide scales have not changed significantly (figs. 7 and 8). They are irregular and multilayered. However, by 25 hours a surface region of porosity is apparent as shown in figure 7. The porosity is due to the formation of Kirkendall voids as a result of chromium diffusion out of the sample.

The identification of the dark areas as pores results from extensive electron microscopy on $\mathrm{TD} \mathrm{NiCr}$ exposed to high velocity in an arc-jet test facility (ref. 12). By careful polishing followed by cleaning ultrasonically in distilled water prior to examination, the dark areas were clearly revealed to be voids rather than $\mathrm{Cr}_{2} \mathrm{O}_{3}$ particles as has sometimes been suggested. At 50 hours (fig. 8), the porosity is present to a greater depth. The leading edge is shown to demonstrate that the oxide layer and the porosity 


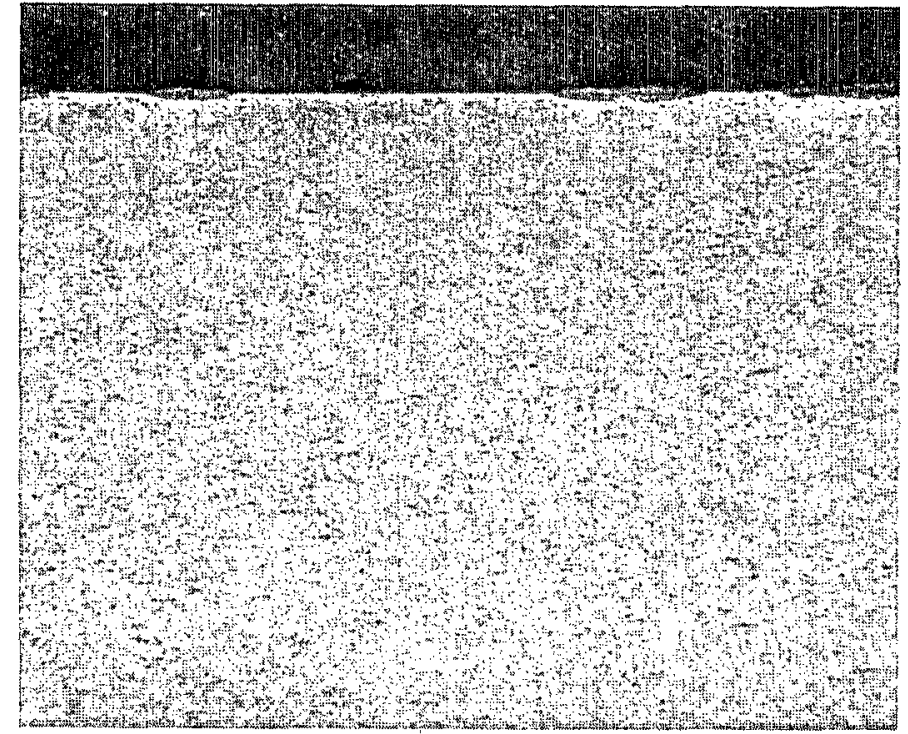

$0.2 \mathrm{~mm}$ (a) Side, X60.

Figure 6. - Microstructures of ground TD NiCr isothermally exposed for 1 hour at $1204^{\circ} \mathrm{C}\left(2200^{\circ} \mathrm{F}\right)$ in high-gas-velocity oxidation apparatus.

$0.02 \mathrm{~mm} \quad$ (b) Side, $\times 500$.

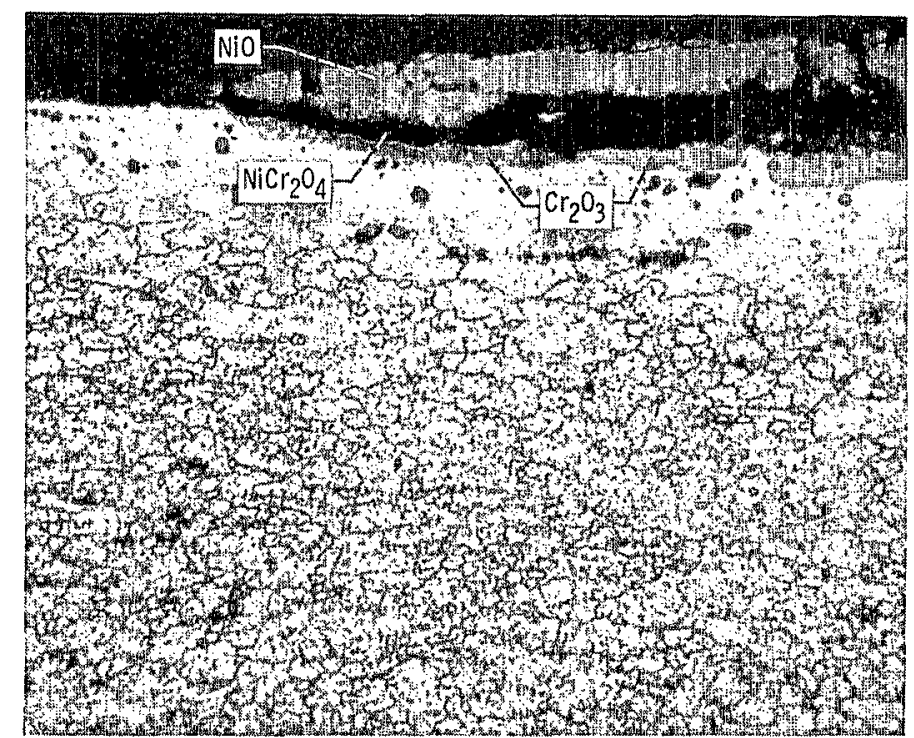




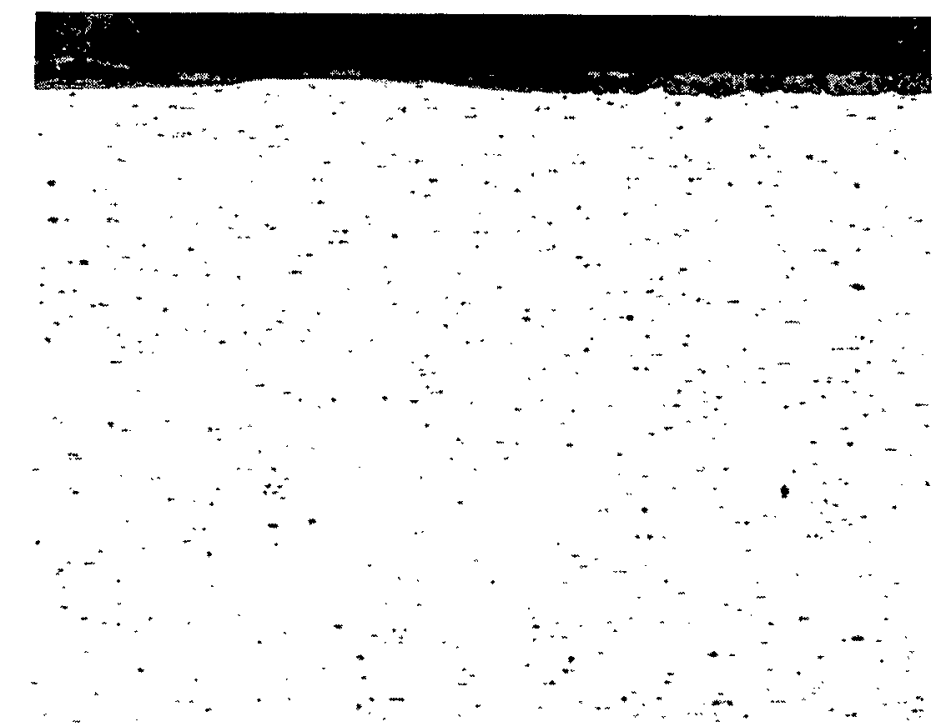

(a) 1 Hour.
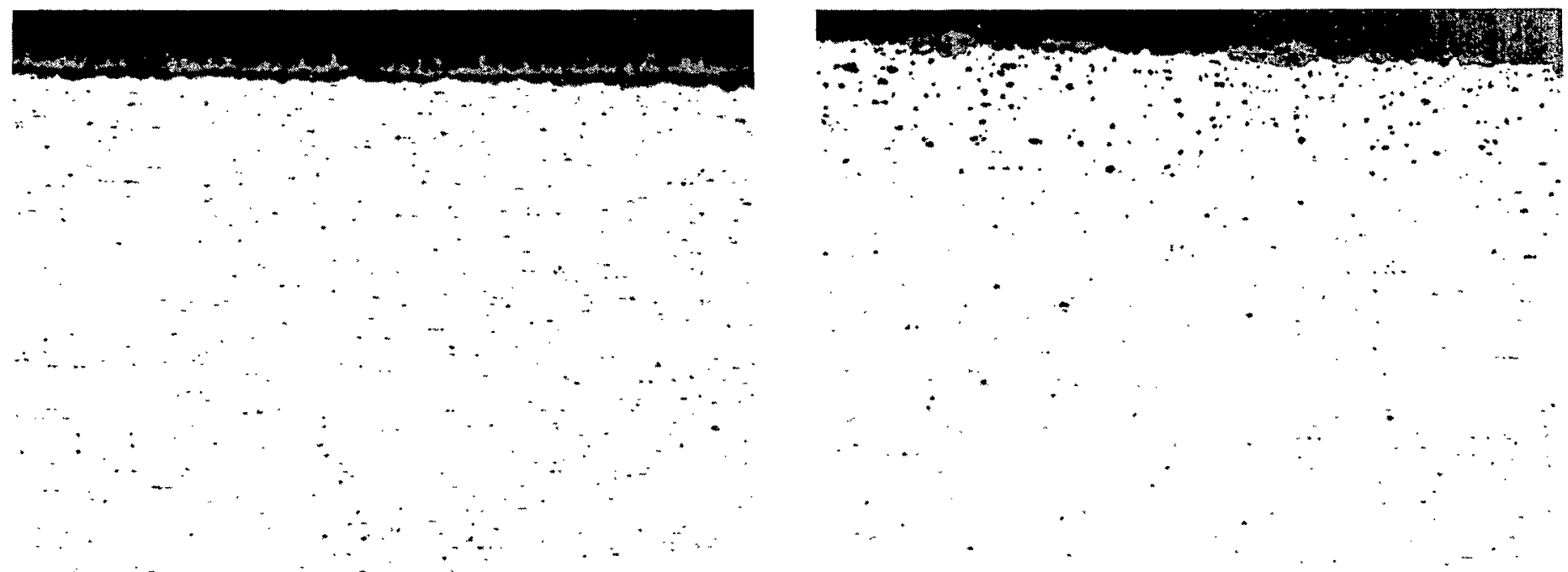

(b) 5 Hours.

$0.1 \mathrm{~mm}$

(c) 25 Hours. 


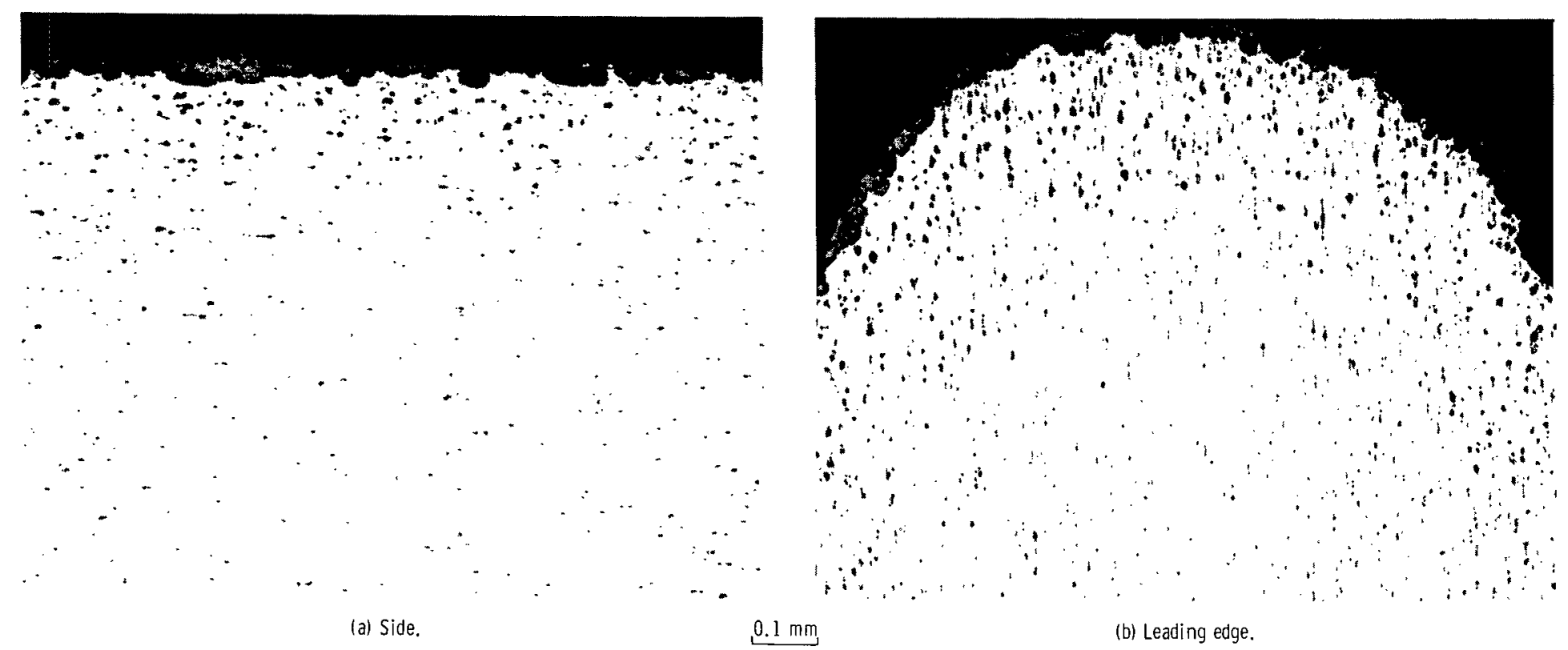

Figure 8. - Microstructures of ground TD NiCr isothermally exposed at $1204^{\circ} \mathrm{C}\left(2200^{\circ} \mathrm{F}\right)$ for 50 hours in high-gas-velocity oxidation apparatus. Unetched; $\mathrm{X} 100$. 
are not qualitatively different from the features observed on the specimen sides. Figure 8 suggests a similarity between the distribution of porosity and the distribution of the original $\mathrm{Cr}_{2} \mathrm{O}_{3}$ particles contained in $\mathrm{TD} \mathrm{NiCr}$. This similarity might suggest that the $\mathrm{Cr}_{2} \mathrm{O}_{3}$ particles are acting as nucleation sites for the Kirkendall voids.

\section{Electron Microprobe Analysis}

Here, as in metallography, the results for ground and polished, cyclic and isothermally exposed specimens are essentially the same. To be consistent, the results obtained with the ground, isothermally exposed specimen are discussed, but the statements in this section apply equally to the other samples.

The probe trace through a blister in the 1-hour-exposed ground sample is shown in figure 9. The trace indicated a high $\mathrm{Cr}$ concentration in the scale near the scale-metal

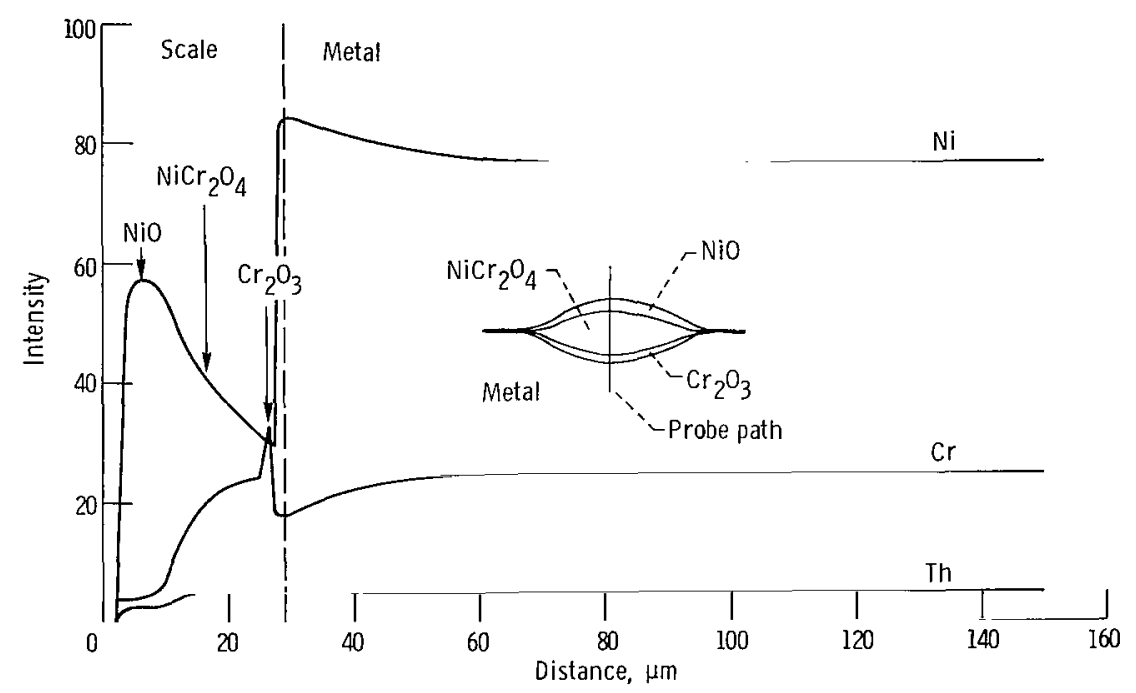

Figure 9. - Microprobe traces on ground TD NiCr after 1 hour isothermal exposure at $1204^{\circ} \mathrm{C}$ $\left(2200^{\circ} \mathrm{F}\right)$ in high-gas-velocity oxidation apparatus.

interface and a high $\mathrm{Ni}$ concentration near the scale-gas interface. These distributions coupled with diffraction results lead to the identification of scale components as indicated in figures 5, 6, and 9. These identifications indicate that a layer of $\mathrm{NiCr}_{2} \mathrm{O}_{4}$ separates the inner layer of $\mathrm{Cr}_{2} \mathrm{O}_{3}$ from an outer layer of $\mathrm{NiO}$.

The $\mathrm{Cr}$ trace of figure 9 also shows a surface depletion of $\mathrm{Cr}$ (and an accompanying $\mathrm{Ni}$ enrichment). This surface loss of $\mathrm{Cr}$ was also indicated by selective etching (fig. 6) and is associated with the observed Kirkendall voids. 


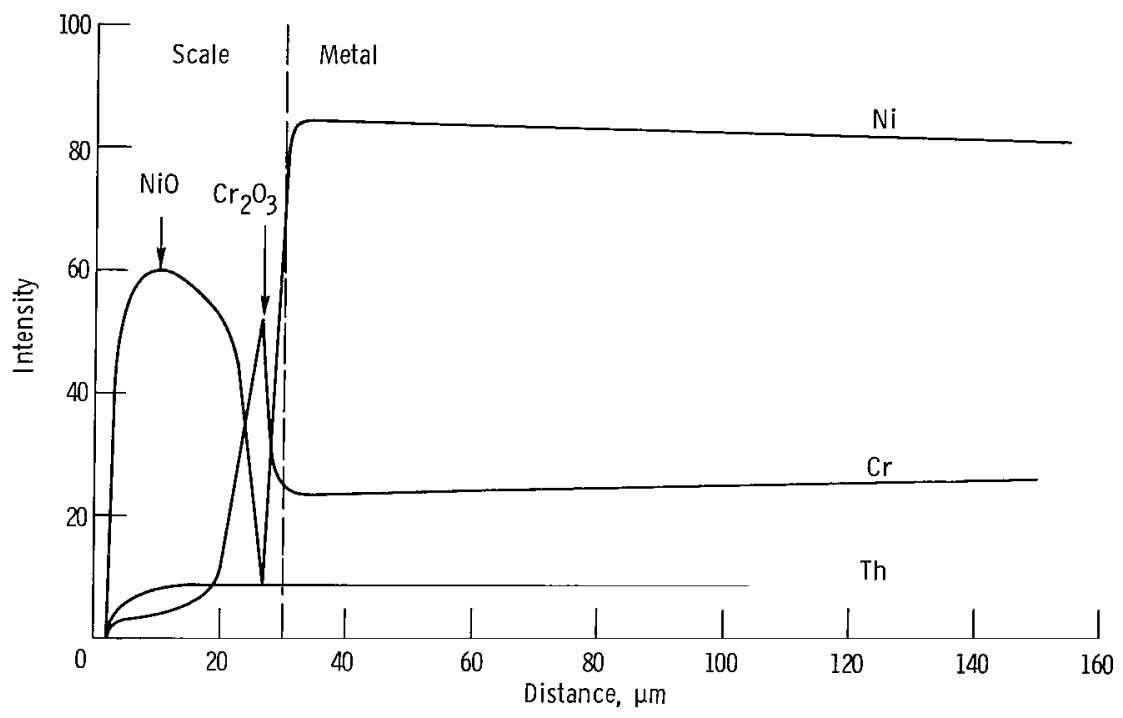

Figure 10. - Microprobe traces on ground TD NiCr after 10 hours isothermal exposure at $1204^{\circ} \mathrm{C}\left(2200^{\circ} \mathrm{F}\right)$ in high-gas-velocity oxidation apparatus.

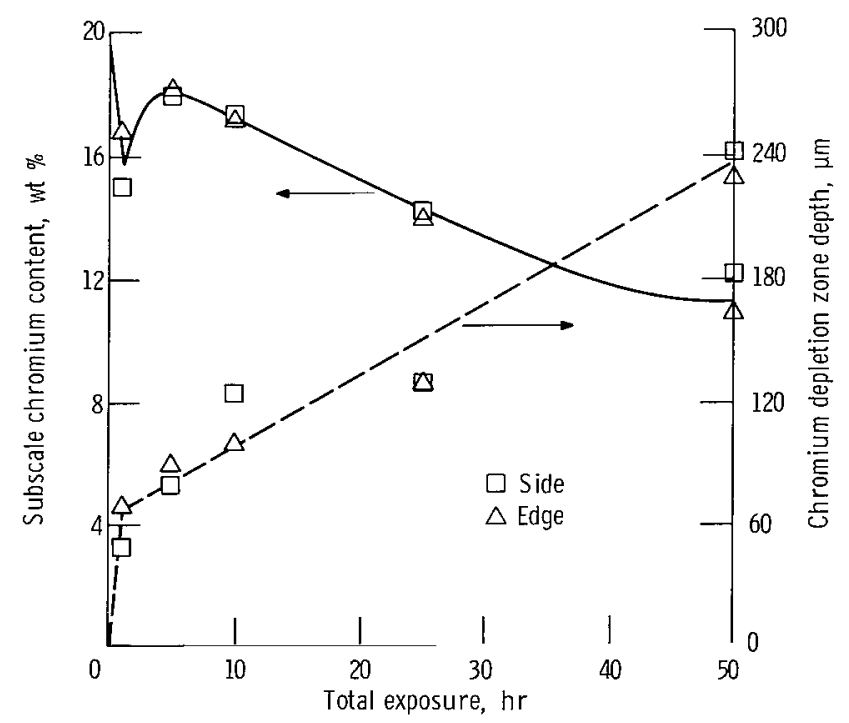

Figure 11. - Subscale chromium content and chromium loss depth for ground TD NiCr isothermally exposed at $1204^{\circ} \mathrm{C}\left(2200^{\circ} \mathrm{F}\right)$ in high-gas-velocity oxidation apparatus. 
Samples other than those exposed for 1 hour are typified by the ground, 10-hourexposed sample whose probe trace is shown in figure 10. Here there is no clearly defined $\mathrm{NiCr}_{2} \mathrm{O}_{4}$ layer, but the positions of the $\mathrm{Cr}_{2} \mathrm{O}_{3}$ and $\mathrm{NiO}$ layers are the same. The $\mathrm{Cr}$ gradient is shallower, but extends much further under the surface.

In an attempt to summarize the probe data, two parameters were taken from the probe scans and are plotted in figure 11. These are subscale $\mathrm{Cr}$ content and the depletion zone depth. The subscale $\mathrm{Cr}$ content was defined as the $\mathrm{Cr}$ value at the oxide-metal interface. The depletion zone depth was defined as the distance below the surface at which the $\mathrm{Cr}$ level reached that of the center of the sample. The data show no systematic differences between side and leading edge, lending support to the metallographic evidence.

Referring to figure 11 , up to 1 hour the depletion zone rapidly expands and the subscale $\mathrm{Cr}$ level rapidly drops. This results from $\mathrm{Cr}_{2} \mathrm{O}_{3}$ volatilizing directly from $\mathrm{Cr}_{2} \mathrm{O}_{3}$, a very rapid process. When the $\mathrm{Cr}_{2} \mathrm{O}_{3}$ breaks down as a result of this volatilization and the surface becomes covered by $\mathrm{NiO}$, the loss of $\mathrm{Cr}$ is retarded. Therefore, the depletion zone growth rate drops. The subscale $\mathrm{Cr}$ content actually increases, as the diffusion of $\mathrm{Cr}$ is faster through the metal than through $\mathrm{NiO}$. This is in agreement with measured diffusion coefficients (ref. 14 and Seltzer, M. S.; Wilcox, B. A.; and Stringer, J.: Development of Oxidation Resistance in Thoriated Nickel-Chromium Base Alloy. $4^{\text {th }}$ Monthly Technical Narrative, May 11, 1971, Battelle Memo. Inst., Columbus, Ohio). When the results of reference 14 and Seltzer, et al., are compared, it appears that $\mathrm{Cr}$ diffuses about four times faster in $\mathrm{TD} \mathrm{NiCr}$ than in $\mathrm{NiO}$ at $1200^{\circ} \mathrm{C}$ $\left(2192^{\circ} \mathrm{F}\right)$. At longer times the subscale $\mathrm{Cr}$ content again decreases as the diffusion path through the metal increases.

\section{Metal Thickness Change}

The isothermal exposure thickness change data are plotted in figure 12. The cyclic data are not shown; however, they are essentially the same as the isothermal data.

The data show little difference between electropolished and ground samples except for short times for the edge values. In addition, the edge loss rate (approximately $160 \mu \mathrm{m} / \mathrm{hr})$ is higher than the side loss rate $(40 \mu \mathrm{m} / \mathrm{hr})$ initially, although for times greater than 1 hour the loss rates appear to be about the same and do not change (approximately $2.5 \mu \mathrm{m} / \mathrm{hr}$ ). After 50 hours of exposure the total edge loss was $310 \mathrm{microm}$ eters, while that of the side was 200 micrometers. The reason for the initially much higher values of the edge data is not clear although it is quite common that corners are more severely attacked than flat surfaces. For a determination of material loss rate the side values are probably more reliable. They are certainly conservative. The data 


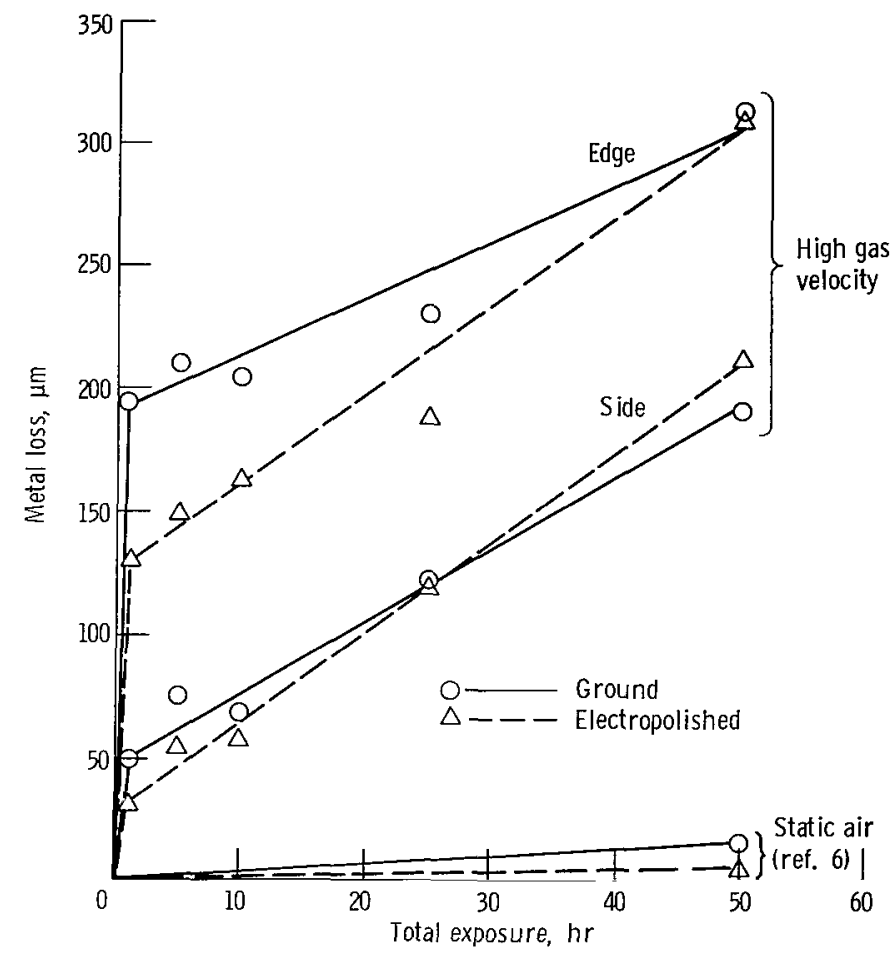

Figure 12. - Metal loss of ground and electropolished TD Nicr isothermally exposed at $1204^{\circ} \mathrm{C}\left(2200^{\circ} \mathrm{F}\right)$ in high-gas-velocity oxidation apparatus compared to static air oxidation of $\mathrm{TD} \mathrm{NiCr}$ at $1200^{\circ} \mathrm{C}$ $\left(2192^{\circ} \mathrm{F}\right)$.

clearly demonstrate that the $\mathrm{Cr}_{2} \mathrm{O}_{3}$ scales allow loss of material more rapidly than when $\mathrm{NiO}$ is the overlayer; the rate of metal loss is 16 times greater in the first hour than at subsequent times. To allow comparison of the current data with static test results, thickness changes (taken from ref. 6) are plotted in figure 12. They indicate that the loss rate of material in a static test is less by 100 times than that of the Mach 1 test.

\section{Oxidation Model}

A schematic diagram of the oxidation of $\mathrm{TD} \mathrm{NiCr}$ at $1204^{\circ} \mathrm{C}\left(2200^{\circ} \mathrm{F}\right)$ in a Mach 1 gas is shown in figure 13 and is divided into three parts. In phase I only $\mathrm{Cr}_{2} \mathrm{O}_{3}$ has formed and the metal loss rate is high. The rate-controlling step is the removal of $\mathrm{CrO}_{3}$ vapor by diffusion through the gas stream, and a chromium-depletion zone is developed in the metal as $\mathrm{Cr}$ diffuses out of the alloy to form more $\mathrm{Cr}_{2} \mathrm{O}_{3}$.

Phase II is a transition step from an all $\mathrm{Cr}_{2} \mathrm{O}_{3}$ scale to a complex trilayered scale with $\mathrm{NiO}$ at the gas-oxide interface, $\mathrm{Cr}_{2} \mathrm{O}_{3}$ at the oxide-metal interface, and $\mathrm{NiCr}_{2} \mathrm{O}_{4}$ between them. The exact cause of this change is not known. The authors feel that the 


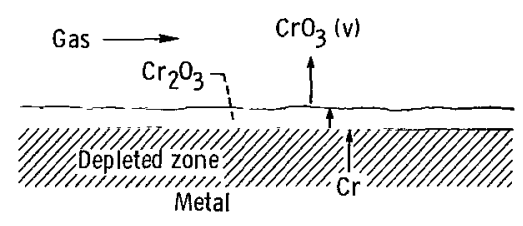

(a) Phase I, up to 1 hour.

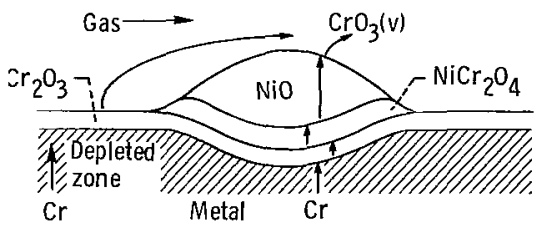

(b) Phase II, approximately 1 hour.

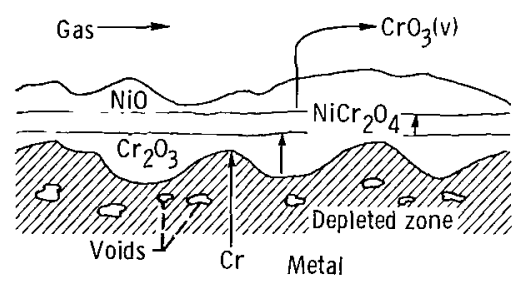

(c) Phase III, more than 1 hour.

Figure 13. - Schematic diagram of oxidation of TD NiCr exposed at $1204^{\circ} \mathrm{C}\left(2200^{\circ} \mathrm{F}\right)$ in highgas-velocity oxidation apparatus.

most likely cause is that a series of local failures or breakdowns of the $\mathrm{Cr}_{2} \mathrm{O}_{3}$ occurs, thereby exposing a chromium-depleted alloy to the hot gas stream. The local breakdowns could have a number of causes. Examples are (1) a more rapid local thinning of the $\mathrm{Cr}_{2} \mathrm{O}_{3}$ by vaporization or (2) a mechanical failure of the $\mathrm{Cr}_{2} \mathrm{O}_{3}$ scale caused by the oxide-metal interface passing through a large $\mathrm{Cr}_{2} \mathrm{O}_{3}$ particle which may be present in the as-received material. In any case, NiO forms at the failure sites on the alloy as the surface $\mathrm{Cr}$ content has dropped below the levels which allow the formation of $\mathrm{Cr}_{2} \mathrm{O}_{3}$. With its inherent rapid growth rate the NiO spreads laterally. This appears to be consistent with local indications of $\mathrm{NiO}$ as suggested by figure 5 .

The final phase shows NiO completely covering the surface with $\mathrm{Cr}_{2} \mathrm{O}_{3}$ at the oxidemetal interface and $\mathrm{NiCr}_{2} \mathrm{O}_{4}$ between. The $\mathrm{NiCr}_{2} \mathrm{O}_{4}$ forms from a reaction between $\mathrm{NiO}$ and $\mathrm{Cr}_{2} \mathrm{O}_{3}$. In order for $\mathrm{CrO}_{3}$ to be lost by vaporization, $\mathrm{Cr}$ must now diffuse from the $\mathrm{NiCr}_{2} \mathrm{O}_{4}$ through the $\mathrm{NiO}$ to the gas oxide interface. Since the rate of loss is slowed substantially at this point as compared to phase I, the rate-controlling step of phase III must differ from that of phase I. The major difference is the addition of an NiO layer between the source of $\mathrm{Cr}$ and the gas stream. Therefore, the most likely ratecontrolling step is the diffusion of $\mathrm{Cr}$ through the NiO. 


\section{SUMMARY OF RESULTS}

The work deals with the oxidation of $\mathrm{TD} \mathrm{NiCr}$ at $1204^{\circ} \mathrm{C}\left(2200^{\circ} \mathrm{F}\right)$ for times up to 50 hours in a Mach 1 gas stream. The samples were oxidized cyclically and isothermally in both the as-ground and as-polished conditions. The oxidation behavior of TD NiCr in these environments was judged by weight changes, X-ray diffraction, metallography, electron microprobe analysis, and metal thickness loss. The major findings were as follows:

1. Thermal cycling had no effect on either the metal loss rate or the sequence of oxide formation as compared to the isothermally heated samples.

2. Both ground and polished samples gave the same results.

3. The sequence of oxide scale formation for both cyclic and isothermal exposures was as follows:

a. $\mathrm{Cr}_{2} \mathrm{O}_{3}$ formed initially with a corresponding rapid loss of metal of about 40 micrometers per hour.

b. At approximately 1 hour, the $\mathrm{Cr}_{2} \mathrm{O}_{3}$ layer failed locally and $\mathrm{NiO}$ began to form a continuous layer over the entire surface.

c. When the NiO overlayer was complete, the rate of metal consumption dropped to about 2.5 micrometers per hour.

d. The NiO overlayer remained for the duration of the test $(50 \mathrm{hr}$ ), and the metal loss rate stayed the same.

4. After 50 hours exposure for cyclic or isothermal tests, the thickness loss was approximately $200 \mathrm{micrometers.}$

\section{CONCLUDING REMARKS}

The results of this work show a strong influence of gas velocity on the oxidation behavior of $\mathrm{TD} \mathrm{NiCr}$. In 50 hours $\mathrm{TD}$ NiCr lost approximately 15 times as much metal in a Mach 1 oxidizing gas stream as in static air tests.

The mechanism of oxidation of $\mathrm{TD} \mathrm{NiCr}$ in a high-velocity gas stream can be broken down into three phases which are characterized by the oxides present on the surface of the alloy. Phase I is characterized by the presence of only $\mathrm{Cr}_{2} \mathrm{O}_{3}$ on the surface. At this point the rate-controlling step is the transport of $\mathrm{CrO}_{3}$ vapor into the gas stream and away from the sample. This initial rate is quite high. Phase II is a transition from a $\mathrm{Cr}_{2} \mathrm{O}_{3}$ outer layer to a $\mathrm{NiO}$ outer layer. This transition was in progress after about 1 hour and was complete after 5 hours. In phase $I I$, NiO covered the surface. Since the rate of metal loss in phase III is less than one-tenth that of phase I, the ratecontrolling step can no longer be the same. The limiting step is now the diffusion of $\mathrm{Cr}$ through the NiO. This is an important point, and one that has not been taken into ac- 
count in mass-transfer calculations and predictions. In such calculations it is assumed that the rate-controlling step is the transfer of $\mathrm{CrO}_{3}$ vapor across the gas boundary layer and remains so at all times. The present work appears to show that this is not the case. Rather, it appears that $\mathrm{Cr}$ diffusion through $\mathrm{NiO}$ is the rate-controlling step after the first few hours. A possible consequence of this is that mass-transfer predictions would be too low. This prediction of low rates results from the use of mass-loss values only from long-time data and does not include the large initial loss which occurs in short times.

Surprisingly, no effect of surface preparation was found at high velocity to correspond to that found in static tests. Similarly, no effect of cycling was noted. This latter result strongly suggests that spalling has only a minor effect.

In general, the effect of high velocity was to greatly accelerate oxidation of $\mathrm{TD} \mathrm{NiCr}$ as compared to static behavior, primarily as a result of loss of the $\mathrm{Cr}_{2} \mathrm{O}_{3}$ scale. This acceleration will limit the usefulness of this material in both jet engine and shuttle applications. For such applications it appears that $\mathrm{TD} \mathrm{NiCr}$ will have to be protected by coatings or alloyed so that a nonvolatile oxide, such as $\mathrm{Al}_{2} \mathrm{O}_{3}$, will form on the surface instead of $\mathrm{Cr}_{2} \mathrm{O}_{3}$.

Lewis Research Center,

National Aeronautics and Space Administration,

Cleveland, Ohio, August 30, 1971, 134-03. 


\section{APPENDIX - CALCULATION OF OXIDE EVAPORATION RATES FROM THE LANGMUIR EQUATION}

The Langmuir equation as given in reference 7 is

$$
G=\frac{P}{17.14}\left(\frac{M}{T}\right)^{1 / 2}
$$

where $G$ is the rate of evaporation in grams per centimeter squared per second, $P$ is the vapor pressure of the evaporating species in torr, $M$ is the molecular weight of the evaporating species, and $\mathrm{T}$ is the temperature in kelvin. The vapor pressure for $\mathrm{CrO}_{3}$ at $1200^{\circ} \mathrm{C}\left(2192^{\circ} \mathrm{F}\right)$ and an oxygen pressure of 1 atmosphere is $1 \times 10^{-5}$ atmospheres (ref. 8). The most important volatilizing species over $\mathrm{NiO}$ at $1200^{\circ} \mathrm{C}\left(2192^{\circ} \mathrm{F}\right)$ and 1-atmosphere oxygen pressure is $\mathrm{NiO}$ (calculations based on ref. 15). The vapor pressure of $\mathrm{NiO}$ under these conditions is $1.8 \times 10^{-10}$ atmospheres. When these values are used for $P, G$ in equation (1) equals $11.6 \times 10^{-5} \mathrm{gm} / \mathrm{cm}^{2}-\mathrm{sec}$ for $\mathrm{CrO}_{3}$ and $17.9 \times 10^{-10} \mathrm{gm} / \mathrm{cm}^{2}-\mathrm{sec}$ for $\mathrm{NiO}$. When these rates are converted to metal thickness losses, they equal $3.02 \times 10^{2}$ micrometers per hour from $\mathrm{Cr}_{2} \mathrm{O}_{3}$ vaporization and 4. $90 \times 10^{-3}$ micrometer per hour from $\mathrm{NiO}$ vaporization. At $10^{-2}$ atmospheres oxygen pressure, these metal loss values are 3.02 micrometers per hour from $\mathrm{Cr}_{2} \mathrm{O}_{3}$ and reremain $4.90 \times 10^{-3}$ micrometer per hour from $\mathrm{NiO}$. 


\section{REFERENCES}

1. Caplan, D.; Harvey, Alma; and Cohen, M.: Oxidation of Chromium at $890^{\circ}$ $1200^{\circ}$ C. Corrosion Sci., vol. 3, 1963, pp. 161-175.

2. Tedmon, C. S., Jr.: The Effect of Oxide Volatilization on the Oxidation Kinetics of $\mathrm{Cr}$ and Fe-Cr Alloys. J. Electrochem. Soc., vol. 113, no. 8, Aug. 1966, pp. $766-768$.

3. Anon.: TD Nickel-Chromium. DMIC Tech. Note, Battelle Memorial Inst., Nov. 2, 1967.

4. Douglass, D. L.; and Armijo, J. S.: Improved Oxidation Resistance of Nickel and Cobalt Superalloys. Quart. Prog. Rep. No. 2, Stanford Res. Inst. (NASA CR91895), Dec. 21, 1967.

5. Rhee, S. K.; and Spencer, A. R.: Oxidation of Commercial High-Temperature Alloys. Metallurg. Trans., vol. 1, no. 7, July 1970, pp. 2021-2022.

6. Lowell, Carl E.; Deadmore, Daniel L.; Grisaffe, Salvatore J. ; and Drell, Isadore L.: Oxidation of $\mathrm{Ni}-20 \mathrm{Cr}-2 \mathrm{ThO}_{2}$ and $\mathrm{Ni}-30 \mathrm{Cr}-1.5 \mathrm{Si}$ at $800^{\circ}, 1000^{\circ}$, and $1200^{\circ} \mathrm{C}$. NASA TN D-6290, 1971.

7. Dushman, Saul: Scientific Foundations of Vacuum Techniques. Second ed., John Wiley \& Sons, Inc., 1962, pp. 17-22.

8. Kohl, Fred J.; and Stearns, Carl A.: Vaporization of Chromium Oxides from the Surface of TD-NiCr under Oxidizing Conditions. NASA TM X-52879, 1970.

9. Fryburg, George C.: The Pressure Dependency in the Oxidation of Platinum Explained by a Boundary-Layer Diffusion Mechanism. Trans. AIME, vol. 233, no. 11, Nov. 1965, pp. 1986-1989.

10. Graham, H. C.; and Davis, H. H.: Oxidation/Vaporization Kinetics of $\mathrm{Cr}_{2} \mathrm{O}_{3}$. J. Am. Ceram. Soc., vol. 54, no. 2, Feb. 1971, pp. 89-93.

11. Johnston, James R.; and Ashbrook, Richard L.: Oxidation and Thermal Fatigue Cracking of Nickel- and Cobalt-Base Alloys in a High Velocity Gas Stream.

NASA TN D-5376, 1969.

12. Centolanzi, Frank J.: Hypervelocity Oxidation Tests of Thoria Dispersed Nickel Chromium Alloys. NASA TM X-62015, 1971.

13. Anon.: TD Nickel Chromium Sheet. Tech. Data Bull. S-TC-S-01-R-1, Fansteel, Inc., Metals Div., Dec. 1, 1969. 
14. Greskovich, C.: Kinetics of $\mathrm{NiCr}_{2} \mathrm{O}_{4}$ Formation and Diffusion of $\mathrm{Cr}^{3+}$ Ions in NiO. J. Am. Ceram. Soc., vol. 53, no. 9, Sept. 1970, pp. 498-502.

15. Grimley, R. T.; Burns, R. P.; and Inghram, Mark G.: Thermodynamics of the Vaporization of Nickel Oxide. J. Chem. Phys. 35, no. 2, 1961. 


\author{
018001 C 1 U 17711119 SO09030S \\ DEPT OF THE AIR FORCE \\ AF WEAPONS LAB (AFSC) \\ TECH LIBRARY/WLOL/ \\ ATTN : E LOU BOWMAN, CHIEF \\ KIRTLAND AFB NM 87117
}

POSTMASTER: If Undeliverable ( Section 158

"The aeronantical and space activities of the United States shall be conducted so as to contribute. . . to the expansion of buman knowledge of phenomena in the atmosphere and space. The Administration shall provide for the widest practicable and appropriate dissemination of information concerning its activities and the results thereof."

- National Aeronautics and Space ACt of 1958

\title{
NASA SCIENTIFIC AND TECHNICAL PUBLICATIONS
}

TECHNICAL REPORTS: Scientific and technical information considered important, complete, and a lasting contribution to existing knowledge.

TECHNICAL NOTES: Information less broad in scope but nevertheless of importance as a contribution to existing knowledge.

TECHNICÁL MEMORANDUMS:

Information receiving limited distribution because of preliminary data, security classification, or other reasons.

CONTRACTOR REPORTS: Scientific and technical information generated under a NASA contract or grant and considered an important contribution to existing knowledge.
TECHNICAL TRANSLATIONS: Information published in a foreign language considered to merit NASA distribution in English.

SPECIAL PUBLICATIONS: Information derived from or of value to NASA activities. Publications include conference proceedings, monographs, data compilations, handbooks, sourcebooks, and special bibliographies.

\section{TECHNOLOGY UTILIZATION}

PUBLICATIONS: Information on technology used by NASA that may be of particular interest in commercial and other non-aerospace applications. Publications include Tech Briefs, Technology Utilization Reports and

Technology Surveys.

Details on the availability of these publications may be obtained from:

SCIENTIFIC AND TECHNICAL INFORMATION OFFICE 